\title{
Red sea crustacia and gastropod shells of ras sudr region (northeast of the Gulf of Suez), Egypt
}

\author{
Salwa A. H. Hamdi \\ Department of Zoology, Faculty of Science, Cairo University, Egypt
}

\begin{abstract}
$\mathrm{O}$ ne crustacean shell from cirripedia, and 24 gastropod shells related to 13 different families are collected and described from Ras Sudr region (northeast Gulf of Suez), Egypt. These include one species from vermetidae, three species from Trochidae, one species from Turbinidae, one species from Neritidae, one species from Turritellidae, five species from Cerithiidae, three species from Strombidae, one species from Fasciolariidae, one species from Melongenidae, four species from Muricidae, two species from Cypraeidae and one species from Naticidae.
\end{abstract}

Key words: Red Sea, Crustacea, Gastropoda, Shells, Ras Sudr, Egypt.

\section{INTRODUCTION}

The Red Sea represents a source of a large group of structurally unique natural products that are mainly found in invertebrates such as gastropods and other molluscs. It is interesting to note that the majority of marine compounds currently in clinical trials or under preclinical evaluation are produced by these species rather than as secondary metabolites by marine algae. Through the combined efforts of chemists and pharmacologists, a number of promising compounds have been identified that are already at advanced stages of clinical trials. This is the case for conotoxins derived from cone snails (gastropods), where a number of conopeptides are currently being developed as analgesics for the treatment of neuropathic pain. More recently, submersible vehicles have allowed the collection of organisms from the water depths. By the 1970s, the search for drugs from animals was a vigorous work that continues today; several marine natural products are currently undergoing advanced pre-clinical studies or are in clinical trials. However, many of the marine organisms remain to be explored and examined for useful bioactive compounds (Attaway, 1993).

The Red Sea is a body of warm tropical water, nearly $2000 \mathrm{~km}$ in length, borded mainly by desert and rocks. These sandy and rocky borders have little visible life, in contrast to the wealth of the marine life found below the water's surface of which most famous are the Red Sea's beautiful coral reefs, which give shelter to a wide variety of animal species. The empty shells of molluscs are frequently washed up on the beaches. For many years, the richness of marine life has attracted explorers and scientists, and in the last decades many tourists as 
well. The Red Sea forms the most northwestern part of the vast Indo-Pacific ocean, it's closest point to Europe.

The book "Red Sea shells" by Sharbati (1984) was the first to show photographs of many Red Sea Shells, but is now out of print.

A compilation of all the known mollusc species was made by Dekker and Orlin (2000), but contained no pictures. What has been missing is a book which is easy to access and read, and contains photographs of most common shells found on the beach and through diving.

Rusmore-Villaume (2008) has searched the beaches of Egypt for fifteen years to establish a book (Sea Shells of the Egyptian Red Sea). This book is intended to serve as a guide to a wide selection of the shelled molluscs of the Red Sea in Egypt and includes all the commonly seen species. But the selection in this book is in no way exhaustive, it was unfortunately impossible to include everything because the author collected the shells from many regions along the Red Sea through fifteen years. So, it was found that every region in the Red Sea in Egypt must be studied alone to reveal the impact of industrial activity, the demands of tourism and the divers, the scientists specially the conchologists as well as the ecologists for future comparisons as climate change progresses. In this study, the common sea shells of Ras Sudr (northeast of the Gulf of Suez) and their biodiversity was studied.

\section{Collection of shells:}

\section{MATERIAL AND METHODS}

Empty shells were collected usually when walking along the beach (or creeping and crawling in case of micro shells!) from the Ras Sudr region on the northest Gulf of Suez, Red Sea, Egypt. Shells were cleaned with a stiff brush or by gently scraping with a needle. They were then wiped over with paraffin or oil. Individual shells were measured and typical shell species were photographed by the author.

The relative abundance and frequency of occurrence of a species is indicated as follows:

- Abundant: where a great number of specimens on the beach are found.

- Common: at least ten specimens were obtained on any given day.

- $\quad$ Uncommon: Not often and not many.

- $\quad$ Rare: Very fewer specimens were found.

A note about naming of the specimens:

The shell names in this paper have been taken from the check-list of Red Sea Mollusca by Abbott and Peter (1986), Dekker and Orlin (2000) and Egyptian Red Sea shells by Rumore Villaume (2008). 
- $\quad$ The designation "of some authors ": means that one or more authors have referred to this creature by the name shown. However, this is not the correct name of the species under discussion, it refers to a different species.

- Synonym: A name published later than the original valid name for the same organism or group of organisms.

\section{Phylum: Arthropoda}

\section{RESULTS}

Class: Crustacea

\section{Subclass: Cirripedia}

Barnacles cling to hard substratum and stay attached to them as they filter fead. Many are found in the intertidal region where pressure is high from predation, dessication, wave action and competition for space.

\section{Tetraclita rufotincta Pilsbry, 1916 (35 mm)}

This shell called "barnacle" was the only crustacean shell found in Ras Sudr region. The shell has a hole at the top (opening).

\section{Phylum: Mollusca}

Class: Gastropoda

Family: Vermetidae (worm shells) $(60 \mathrm{~mm})$

Worm shells live fixed to the substrate.

Dendropoma maxima (Sowerby, 1825) $(60 \mathrm{~mm})$

They are found as worm tubes in the coral collection.

Distribution: Rare.

Family Trochidae: Top shells

Trochidae live in shallow and deep water. They have characteristic colours and triangular shape.

\section{Clanculus pharaonius (Linnaeus, 1758) (15 mm)}

Strawberry top shell

With bright pink or red colour. The shell has a tight spiral rows of pink, black and white beads.

Distribution: very common

Trochus erithreus Brocchi, 1821 (25 mm)

The shell is pyramidal in shape with small knobs arranged in spiral rows. The shells have pink and white or red and white colours.

Distribution: abundant.

Tectus dentatus (Forsskal in Niebuhr, 1775) $(75 \mathrm{~mm})$

The shell is pyramidal in shape with big knobs. $(100 \mathrm{~mm})$

Distribution: common

\section{Family: Turbinidae}

Turbinidae have a strong, thick calcareous operculum readily distinguishing them from the somewhat similar trochidae or top snails, which have a corneous operculum. 


\section{Turbo radiatus Gmelin, 1791 (30 mm)}

The shells have beige and brown colours. The shell is divided to upper small spiral rows of small knobs and lower big spiral rows of somewhat big knobs. In some specimens, the knobs are very small in the upper and lower regions of the shell.

Distribution: Common

\section{Family: Neritidae}

Neritidae are also known as slipper winkles, and have very characteristic colours.

Nerita sanguinolenta Menke, 1829 (25 mm)

The shells have two different colour patterns: black and white or beige and brown, or bright orange and white.

Distribution: Very common

Family: Turritellidae:

Shells of this family have pointed end with rounded whorls. The aperture lacks folds or thickness of outer lip, and has no siphonal canal.

\section{Turritella torulosa Kiener, 1843 (37 mm)}

A long, slender, light-weight shell. The shell whorls have spiral ridges. The base of the last whorl is sharply keeled and the aperture is round. The shell has white-pink colour.

Distribution: Rare

\section{Family Cerithiidae:}

Correct identification of ceriths is difficult because individuals of the same species, even from the same location, may show many differences. In addition, the shape and appearance of the shell may change a great deal during it's growth from juvenile to immature to fully mature adult.

\section{Cerithium adansonii Bruguiere, 1792 (55 mm)}

Synonym Cerithium erythraeonense Lamarck, 1822

Large shell with regular knobs, and with brown or white colour.

Distribution: common

\section{Cerithium columna Sowerby, 1834 (55 mm)}

The crenulated lip of this shell is curved to cross the siphonal canal at nearly 90 degrees.

\section{Cerithium sp. juvenile (37 mm)}

Small sized shell with long canal.

Distribution: Common

\section{Cerithium caeruleum Sowerby, 1855 (35 mm)}

The shell is reddish brown with arranged spirally nodules and white aperture.

Distribution: Common

\section{Clypeomorus bifasciata (Sowerby, 1855) (18 mm)}

The shell always has pink, brown touchable dots alternative with white or brown colour.

Distribution: Common

Family Strombidae: 
Strombids have extravagant shapes and colours, the shells are commonly known as conches.

Tricornis tricornis (Lightfoot, 1786) (35-120 mm)

Synonym Strombus tricornis Humphrey, 1786

Adult (100-120 mm): large shells with single extension of the outer lip, maybe long or short.

"Dwarf" by some authors ( $88 \mathrm{~mm})$ : medium shells grow to only $80 \mathrm{~mm}$ and characterise by a very thick or thin outer lip in the mature individual. The protrusion of this shell is not very long.

Immature $(85 \mathrm{~mm})$ : long shells without any extension and have a striation of brown and white colours.

Juvenile $(35 \mathrm{~mm})$ : shells lack the protrusion and resemble fragile cone shell in shape.

Conomurex fasciatus (Born, 1778) (50 mm)

Strombus fasciatus by some authors

The shell is lineated with light to dark brown spiral lines.

Distribution: abundant.

Dolomena plicata plicata (Röding, 1798) (51 mm)

Strombus plicatus plicatus by some authors

The shell has many axial ribs on the spire and inside the outer lip.

Distribution: abundant

Family Fasciolariidae:

Shells have long canals and sometimes called spindle shells.

Fusinus verrucosus (Gmelin, 1791) (85, 60, $45 \mathrm{~mm}$ )

Spindle shaped, beige, yellowish, or light brown shells with purple-mouthed aperture. Distribution: common.

Family: Melongenidae

This family includes several distinctive shell forms. Crown and melon conches are more tropically distributed and typically found in brackish or muddy waters near mangrove forests. All are carnivorous, feeding on clams and oysters.

Volema paradisiaca nodosa (Lamarck, 1822) $(45 \mathrm{~mm})$

The shell has a ring of nodules at the top with smooth surface.

Distribution: Abundant

Family Muricidae:

This is the largest family among the marine snails, have extremely variable shells. All are active predators and tropical or semi-tropical in habitat. Most have radulas.

Murex forskoehlii Röding, 1798 (65 mm)

Shells with white to beige colors with long spines and very long siphonal canal.

Distribution: Moderately common.

Murex scolopax Dillwyn, 1817 (40 mm)

White shells with simple nodules protrustions.

Distribution: Rare 


\section{Stramonita lacera (Born, 1778) (55-58 mm)}

Beige to light brown shell, very globose, unusually large, and deep aperture.

Distribution: Rare

\section{Family Trapeziidae:}

Shells in this family have strong teeth, both cardinal and lateral. In most species, the ventral margins are nearly parallel but the ends are irregular.

Thais savigny (Deshayes in Deshayes \& Milne Edwards, 1844) (30 mm)

Shell has four spiral rows of distinct, well-seperated, pointed, grey-brown tubercles.

Distribution: Rare.

\section{Family: Cypraeidae:}

this has about 200 living species. The basic shape of the shell is the same in all species long prized by primitive people for their shape and attractive colors. They were widely used for many ancient times. While cowries are abundant in the tropics, some species are now quite rare and get a very high price from collectors.

Erosaria turdus (Lamarck, 1810) (42 mm)

White shell with large teeth.

Distribution: Common

Mauritia grayana (F.A. Schilder, 1930) (40 mm)

Beige shell with orange to dark brown teeth.

Distribution: Abundant

\section{Family: Naticidae}

This family can be recognized by the shape of their shells, distinct appearance or by their predatory behavior.

Neverita josephina (Risso, 1826) (30 mm)

Moon snail shell, egg-capsule in shape.

Distribution: Common

\section{DISCUSSION}

Neverita josephina is the $1^{\text {st }}$ record to the Suez Canal region, it is a Mediterranean species in origin, might entered the Suez Canal system for some distance towards the Red Sea. Also, Stramonita lacera an introduced species in the Suez Canal area, from where it spreads towards the Red Sea and also towards the Mediterranean sea. They are identified according to Abbott \& Peter (1986) and Dekker \& Orlin (2000).

Tetraclita rufotincta, Dendropoma maxima, Turritella torulosa, and Murex scolopax are reported here for the first time from Egypt. The crustacean and the gastropod Red Sea shells were not included in the recent book of the Egyptian Red Sea shells illustrated by Rusmore-Villaume (2008).

Cerithium sp. may be a new species, because of the small sized shell and long canal. Also, Cerithium columna was reported here for the first time in the Gulf of Suez, since Rusmore-villaume (2008) recorded that neither of then was 
found in the Gulf of Suez. This may be due to the change in climate from that time to the present time of this study.

Great variability in shape was recorded to Fusinus verrucosus, that was identifyied according to Rusmore-villaume (2008), who considered them one species because she found no consistent structural differences between various shapes.

Different colours were recorded to Nerita sanguinolenta from the Ras Sudr region. An interesting point of view is that their colour is similar to the rocks on which they live, where red shell live on red granite rocks, black and white ones on black and white rocks, and greenish ones on greenish rocks! Perhaps their predators are colour-sensitive and pick off the ones that stand out against the rock (Rusmore-villaume, 2008).

According to the economical importance of the gastropods, family Strombidae includes the conches which are an important traditional source of protein for the indigenous shore-dwelling human population (Rusmore-villaume, 2008). In the present study, three species were recorded in family Strombidae. So, the suggestion here that more research has to be done on the different recorded species in Egypt that may play the same role.

Beside the economic importance of aquatic gastropods, it has been found recently that it can be used to derive and isolate chemical compounds which have a therapeutic application and clinical important (McConnell et al., 1994).

In recent clinical pharmacological research, marine natural products will probably become available as novel therapeutic agents to treat multiple disease categories (De Vries \& Beart, 1995). For examples cone snails found in Ras Sudr region could have a sting (conotoxins) that cause terrible pain and even death to humans if caught improperly (Rusmore-villaume, 2008) Moreover, Conotoxins have many therapeutic applications for the treatment of neurological diseases such as multiple sclerosis, shingles, diabetic neuropathy and other painful neurological conditions such as spinal pain (Alonso et al., 2003). More research should be done on the other endemic gastropod species in Egypt that may play a role in medical malacology.

\section{REFERENCES}

Attaway, D.H. and Zaborsky, O.R. eds (1993). Pharmaceutical and Bioactive Natural Products. Marine Biotechnology, Vol. I, Plenum.

Dekker, H. and Orlin, Z. (2000). "Check-list of Red Sea Mollusca", Spirula, 47 (Supplement): 1-46.

Rusmore-villaume, M. (2008). Sea shells of the Egyptian Red Sea. The Amrican University in Cairo Press - Cairo, New York, pp. 158-294. 
Sharabati, D. (1984). Red Sea shells. London, KPI Limited.

Abbott, R. Tucker and Peter, S. Dance (1986). Compendium of seashells. Burlington, MA: American Malacologists.

De Vries, D.J. and Beart, P.M. (1995). Fishing for drugs from the sea: Status and strategies, Trends Pharmacol. Sco., 16: 275-279.

Alonso, D.; Khalil, Z.; Satkunanathan, N. and Livett, B.G. (2003). Drugs from the sea: conotoxins as drug leads for neuropathic pain and other neurological conditions. Mini Rev. Med. Chem., 3: 785-787.

McConnell, O.J.; Langley, R.E. and Koehn, F.E. (1994). The discovery of marine natural products with therapeutic potential, in the discovery of marine Natural Producers Wairh Therapeuti Potential (Gullo, V.P. ed.), pp. 109-174, Butterworth-Heinemann. 
Photo 1 :Family Cirripedia, Family Vermetidae, Family Trochidae and Family Turbinidae

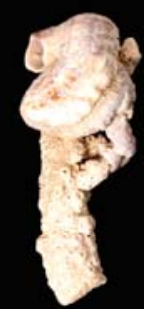

Dendropoma maxima

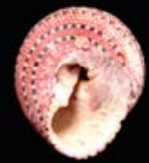

Clanculus pharaonius

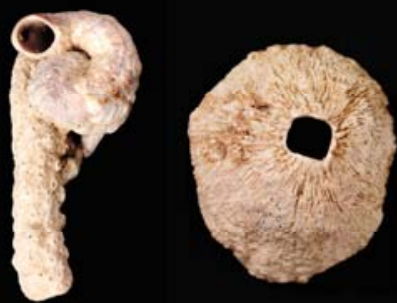

Tetraclita rufotincta
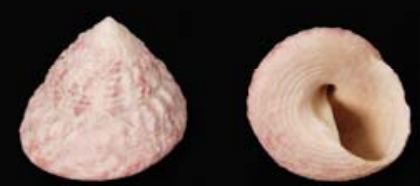

Trochus erithreus

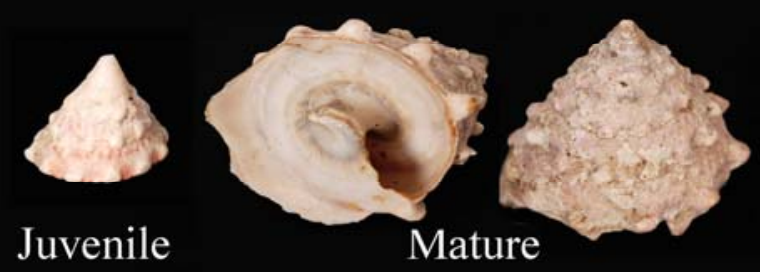

Tectus dentatus
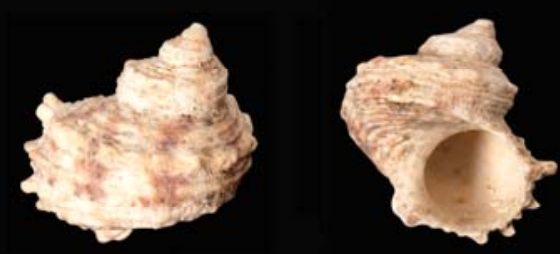

Turbo radiatus 
Photo 2:Family Neritidae, Turitiellidae\&Cerithiidae 60

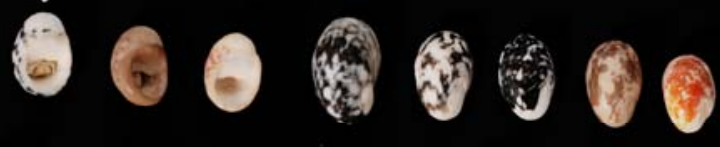

(2) 8

Nerita sanguinolenta

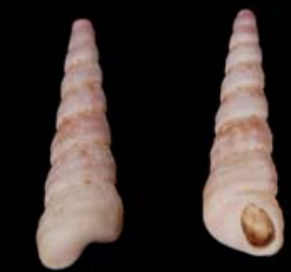

Turritella torulosa

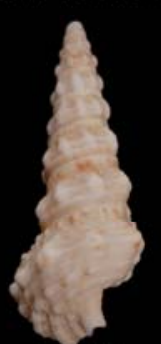

Cerithium adansonii
(6)

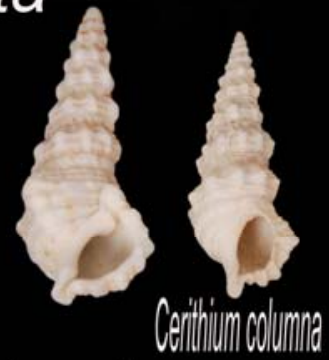
Juvenile

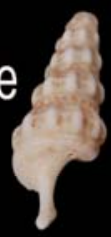

Cerithium caeruleum Cerithium sp.

Clypeomorus bifasciata 


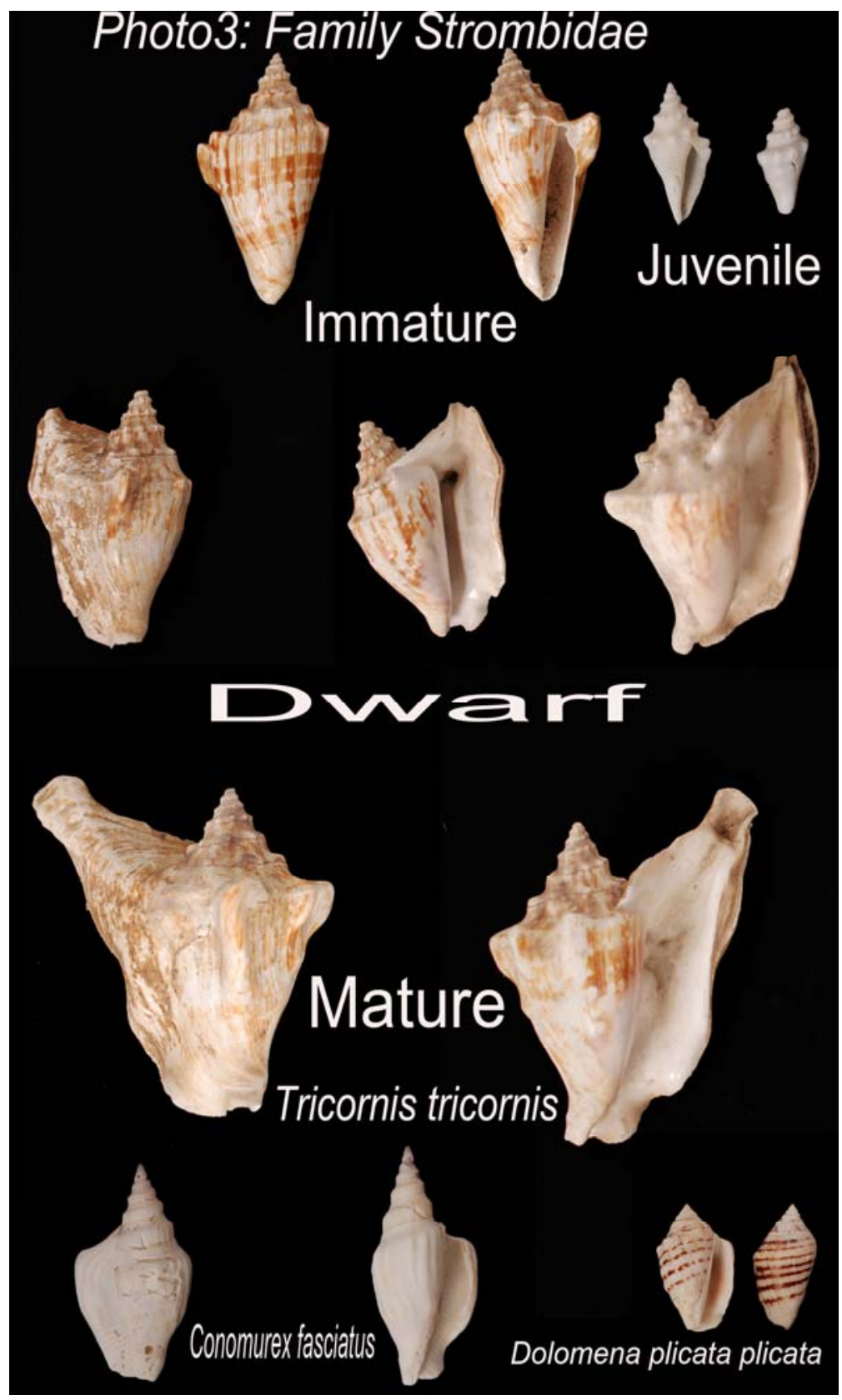




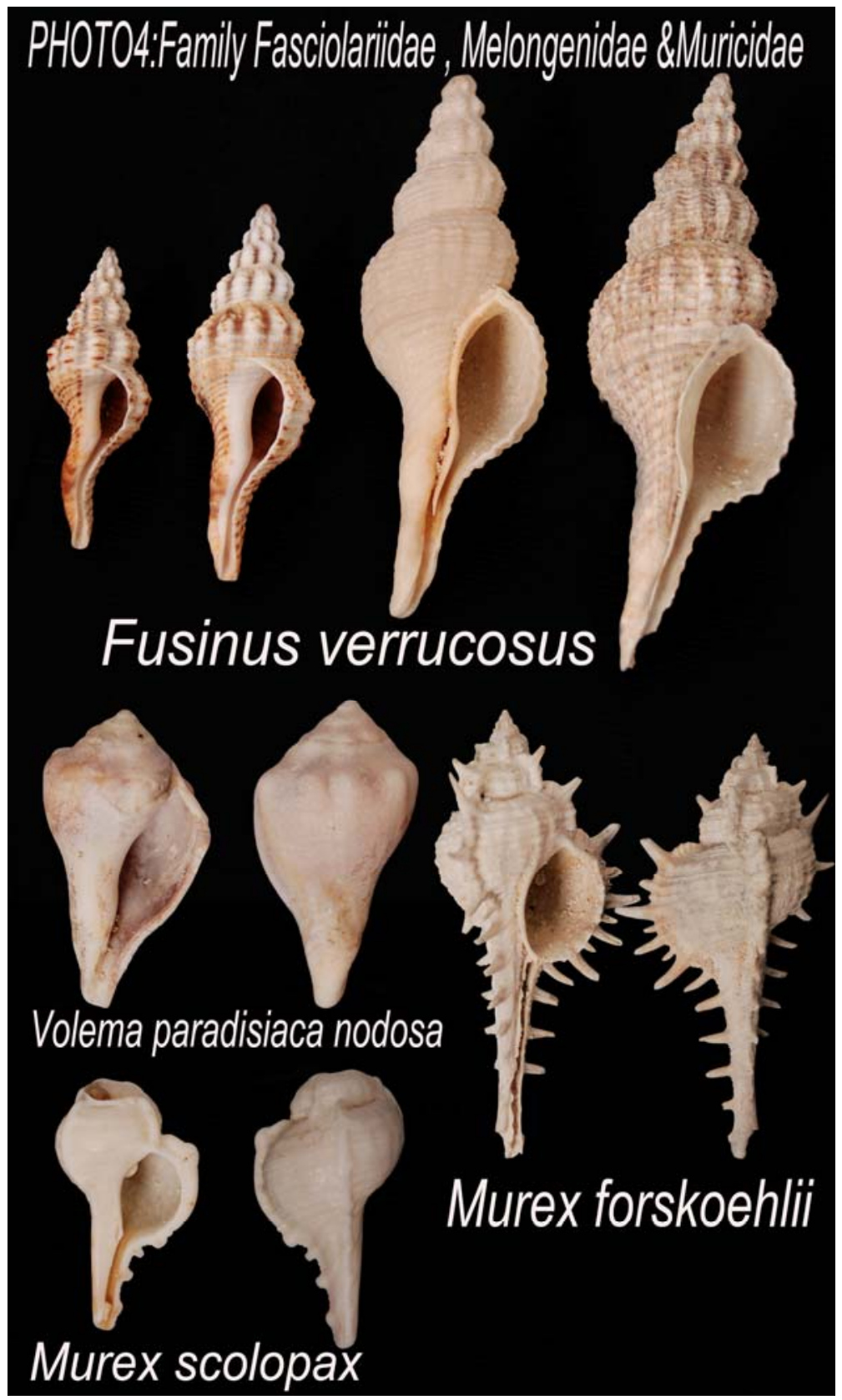


Photo 5: Family Muricidae, Cypraeidae\&Natacidae
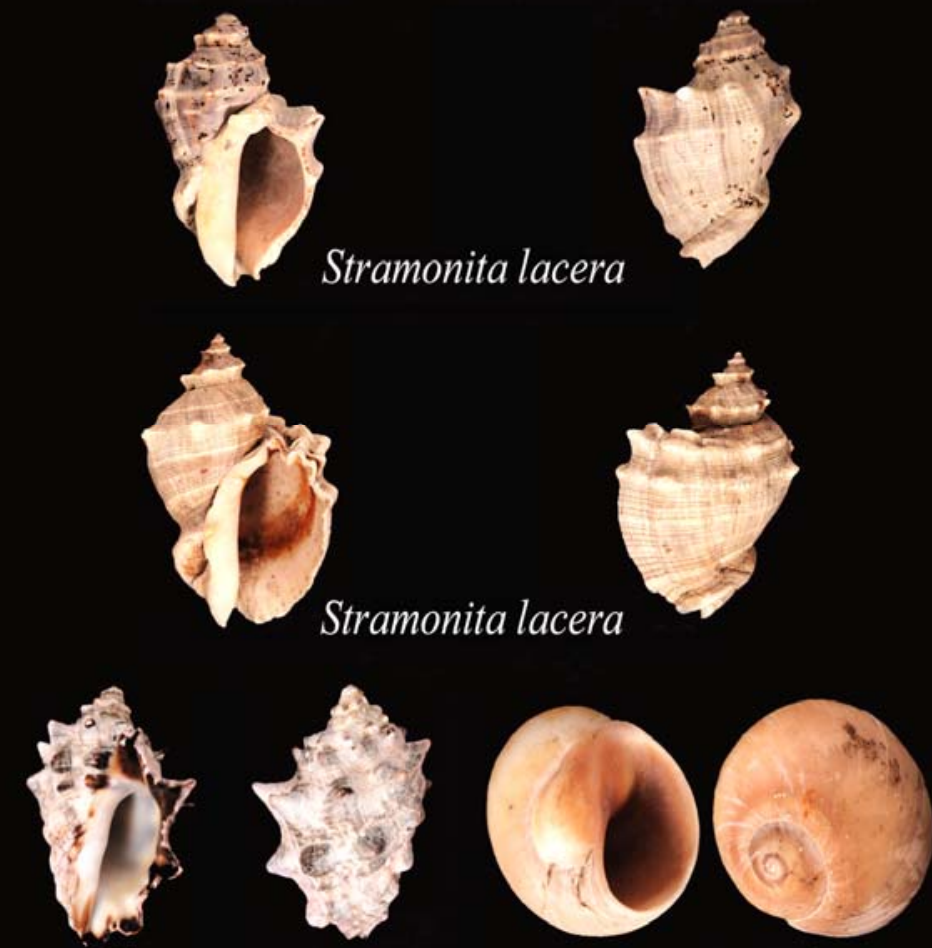

Thais savignyi

Neverita josephina
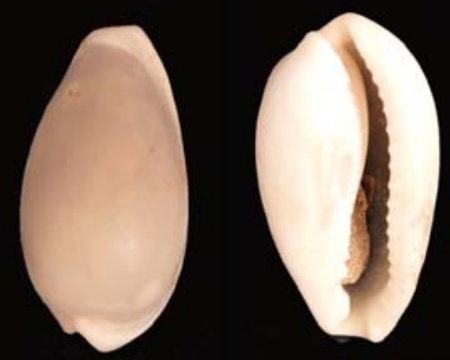

Erosaria turdus

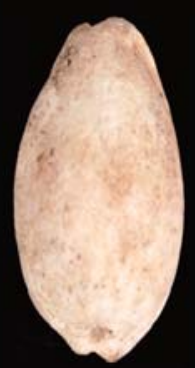

Mauritia grayana
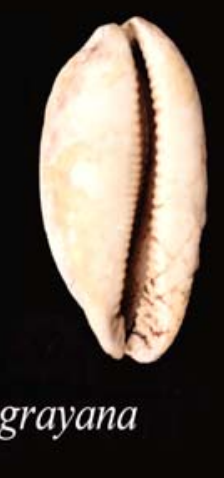